\section{Science, nature, food and politics}

\author{
Food's Frontier: The Next Green Revolution \\ By Richard Manning
}

North Point Press, \$24.00, ISBN 0-86547-593-8, 2000

\section{Pandora's Picnic Basket: The Potential and Hazards of Genetically Modified Foods \\ By Alan McHughen \\ Oxford University Press, \$25.00, ISBN 0-19-850674-0, 2000}

\section{Review ed by Eric Brunner}

Senior Lecturer in Epidemiology and Public Health, University College London, London, UK

In 1969, as world population growth looked likely to overtake food supply, biologist Paul Ehrlich predicted famine and food war in Southeast Asia. This Malthusian prophecy was wildly inaccurate at the time. Between 1950 and 1990, improving farming methods, in part due to the widespread use of high-yielding, conventionally bred rice and wheat varieties, led to a tripling of harvests and a decline from some $60 \%$ to $10 \%$ in the worldwide prevalence of energy-deficient diet. But in the last ten years, productivity growth has slowed down. In 2001 there are valid questions about both the sustainability of the current food system in relation to future population growth and the longer-term environmental effects of

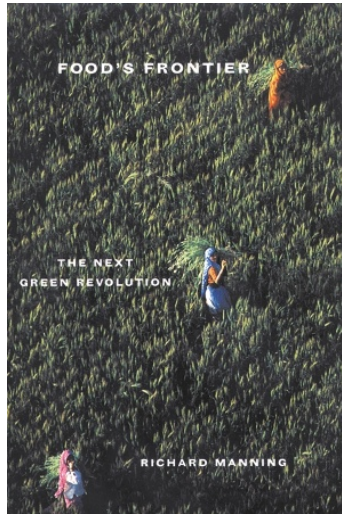
intensive agriculture.

One important way the policy debate splits is over different visions of a new green revolution: high-tech versus low-tech. Thankfully, environmental writer Richard Manning, in Food's Frontier, goes beyond these entrenched positions. His lucid book, based on a study tour of Africa, Asia, and Central and South America, brings the reader eyeball to eyeball with real-life farming

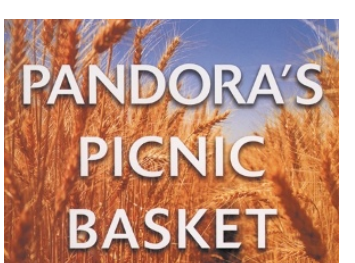

solution involving an effective protease inhibitor from peanuts. Varieties of chickpea that are resistant to pod borers have not been found, so this appears to be a logical approach, but it has yet to be successful. In contrast, using traditional plant-breeding methods, workers at the same institute have developed novel chickpea varieties that are resistant to Fusarium fungal wilt, based on the identification of inherently resistant varieties. Manning illustrates through his reportage that use of biotechnology to the exclusion of conventional breeding methods is likely to be inefficient. Existing technologies can be and are being used to great effect, but in many developing countries they remain remarkably and sometimes fatally underused. Whereas Manning places his discussion of biotechnology within specific developing world socio-economic and environmental contexts, Alan McHughen's primer on genetically modified (GM) foods focuses on the underlying science and technology. Pandora's Picnic Basket provides a popular treatment of key technical topics, for example, "Home cooking! DIY guide to genetic engiproblems and current attempts to solve them. His case studies make the point that science and nature cut across political views. In India, for example, traditional chickpea cultivars are defenseless against attack from pod borer (Helicoverpa) larvae, which in a bad year can destroy an entire crop. Researchers in Pune have shown that the pod borer's resistance to the chickpea's endogenous insecticidal protease inhibitors is a product of natural selection, and is not the result of reliance on artificial pesticides. The Indians are working on a transgenic improving the linseed transformation technique, we were anxious to try something beyond marker genes, something useful. We were like kids given a new computer, but only basic software, no exciting games. I recalled my interest in helping farmers overcome their problems with sulphonyl urea herbicides. A gene conferring resistance to SUs would be a nice bit of software." Given the author's fervor for the technology, his discussion of its implications is understandably fragile. "There are legitimate socioeconomic issues," writes McHughen, "but they are not in the realm of scientific discourse...In any case, it is not scientifically valid to consider socio-economic parameters in what is supposed to be a 'sciencebased' environmental risk assessment. The issues are too disparate and complex to evaluate together." The author does see the likely inevitability of economic disruption in countries including those Manning visited, as developed countries put low-cost GM commodities, such as maize oil, onto the world market. As a molecular biologist, McHughen, perhaps rightly, does not explore the possible responses of the scientific community to such economic issues. To tackle any potential biotechnology downside on the environmental front, he is firmly in favor of risk management rather than the precautionary principle.

McHughen asks why it is that there is much more public resistance to GM food technology in Europe than there is in North America. He recognizes that Europeans are not fundamentally opposed to the underlying technology. Thus the perception on both sides of the Atlantic in the healthcare domain is that there is considerable potential in biotechnology, whereas, as the author says, "there's no public demand for GM food." Consumer preference, as the marketeers would have it, is calling the shots. McHughen also invokes European contempt for the regulatory process as a reason for the transatlantic divide. My experience as an expert advisor to a recent World Health Organization/Food and Agriculture Organization consultation is that, internationally (not just in Europe), scientific standards in the appraisal of GM food safety do indeed leave something to be desired. Perhaps GM food regulation is more cautious in Europe than in North America precisely because Europeans are demanding effective regulatory control over approvals when the benefits and risks are unclear. It would have been useful if Pandora's Picnic Basket had tackled such questions in some depth. In any event, dismissing the "opposition" by quoting the wild ramblings of the Natural Law Party is no way to take the GM food debate forward. 